\title{
THE EFFECT OF SPEECH TRAINING WITH SYSTEMATIC DESENSITIZATION ON ENHANCING STUDENTS' SPEAKING COMPETENCE
}

\author{
${ }^{1}$ SYAFRYADIN, ${ }^{2}$ NURKAMTO, ${ }^{3}$ LINGGAR, ${ }^{4}$ MUJIYANTO \\ ${ }^{1}$ Universitas Negeri Semarang, ${ }^{2,4}$ J. Universitas Negeri Semarang, ${ }^{3} \mathrm{D}$, A. Universitas Negeri Semarang \\ E-mail: Syafryadin2011@gmail.com
}

\begin{abstract}
This study was designed to investigate whether Speech Training with Systematic Desensitization could improve the students' speaking competence or not. This study used an experimental design. The population of this study was all fourth semester students in the English Department in one of Universities in Kendari of academic year 2015/2016. The instruments of this study were speech test, observation checklist, interview guidline and note taking. The data were analyzed quantitatively and qualitatively. The finding of this study was mean score of Speech Training with Systematic Desensitization Technique was 67.36 for pretest and 79.80 for posttest. It indicated that the students' speaking competence got improvement because the increasing of mean score of speech test from pretest to posttest. Thus, Speech Training with Systematic Desensitization Technique could increase the students' speaking competence.
\end{abstract}

Keywords- Speech training, Systemathic Desensitization, speaking competence.

\section{INTRODUCTION}

Speaking is an interactive process of constructing meaning that receives and processes the information. Speaking is used to deliver ideas to the others. It also requires learners not only know how to produce specific points of language such as grammar, pronunciation, or vocabulary Burns and Joyce (as cited in Siam, 2003). Lyons (2001:18) stated that speaking or doing communication is also transferring of feelings, attitudes and thought. Richards (2008:19) states:

"The mastery of speaking skill in English is a priority for many second languages or foreign language learners. Consequently, learners often evaluate their success in language learning as well as the effectiveness of their English course on the basis of how much they feel they have improved in their spoken language proficiency".

The quotation indicates that speaking is the essential skill in English. Luoma (2004:24) said that speaking or spoken interaction is complicated either in the first, foreign or second language. This statement encourages the teachers to give more attention to speaking skill.

Speaking has several skills namely speech, conversation, interview, and discussion. Speech is one of the speaking skills that students always do either in the academic setting or non-academic setting. Martin and Miller (2003) stated that speech refers to the speaking activities which use a good expression, clear voice, and appropriate intonation to support the meaning. Speech is public speaking because public speaking is the act of giving speeches in front of many people (Schmitz, 2012 and Brewer, 2001). O'Hair, Rubenstain, \& Stewart (2010:93) stated that two common genres of speech are informative speech and persuasive speech. An informative speech is aimed to inform the audience about the objects or issue and affect how people see a subject by bringing it to light, or may influence what is seen as important by virtue of directing attention to the subject (Osborn and Osborn, 2014:342). Four types of informative speeches are a description, demonstration, explanation, and briefing. Persuasive speech is aimed to persuade or convince the audience or listeners about the topic that speakers presented. According to O'Hair, Rubenstain, and Stewart (2010:371), persuasive speech is a speech which can effect on listeners' behavior or attitude, and values. German, Groenback and Monroe (2004) explained that persuasive speech has two main goals. Those are the speech to convince and speech to actuate.

Informative and persuasive speech have to be known and learned by the students because speech is one of the materials in the curriculum of the university. Based on curriculum regulation article 9 sub article 2 and 4 of government regulation of Indonesia number 19 in 2005, curriculum in higher education must cover English subject (listening, speaking, reading and writing) and the content of the curriculum is accordance with the university itself. This course is aimed to make the students speak in front of many people in conferences, seminars or other academic events.

Ur (2012:121) stated that students' problems in speaking are inhabitation, nothing to say, low participation and mother tongue use. Meanwhile, Notion and Newton (2009:76) emphasize on fossilized pronunciation which occurs to the students. According to Jhonson, Jhonson \& Smith (2006), two factors that effect on speaking competence are a lack of knowledge skills and self-factors. Lack of knowledge skills consists of grammatical ability, vocabulary, pronunciation, and oral practicing, while self-factors involve students' condition like guilt, fear, worry, anxiety, and poor idea. Some previous research found that foreign language anxiety among 
EFL learners has been singled out as a major factor that impedes the process of language learning and significantly hinders English language proficiency (Liu \& Huang, 2011 and Olivares-Cuhat, 2010). Thus, this speaking anxiety is also related to the students' academic achievement or performance.

Speaking problems explained by the experts similarly happen when the researcher conducted an interview with the lecturers and several students on the students' speaking problems in English department of one of the universities in Kendari. The researcher found that the students were anxious in speaking or doing a speech in front of the classroom because of a lack of preparation, knowledge skill, negative evaluation from the teacher or lecturer and the classmates. The students also made mistakes in terms of vocabulary, grammar, pronunciation, fluency, accuracy and mother tongue use. They are difficult to get a good or appropriate idea of speech. These problems can be solved by giving appropriate techniques or methods. Speech training with Systematic Desensitisation is alternative solution which can be used to enhance the students' speaking competence because in the training, students get much knowledge about speaking elements, how to open, deliver and close the speech.

\section{LITERATURE REVIEW}

\section{Nature of Speaking Competence}

Speaking is one of the productive skills which used to communicate with others. In speaking, it is essential to master fluency and accuracy, thus either speaker or listener will be more understood the essence of meaning. Harmer (2007) stated that speaking is the interaction activity which aimed to deliver messages or ideas. Cameron (2001) points out that speaking is the way to express the meanings of the language. Burns and Goh (2012) stated that speaking is so worth in our daily life and it involves share information to other people, socialize with those around them, express who they are as individuals, ask for things that they want, and get other people to respond to their requests. According to Bailey (2008), speaking is the productive oral skill that includes conveying meaning through producing verbal utterances systematically. In other words, speaking is the process of building and sharing meaning through the use of verbal and non-verbal symbols in a variety of the context. The idea supported by Brown (2007) stated that speaking is an essential skill which has been developed because speaking is the way to transfer, construction, receiving idea or information to other people. Those advantages can be achieved if students are continuously involved in a communicative activity. One of them is an oral presentation or speech.

Thornbury (2005) pointed out that six steps which exist in a process of speaking are the process of conceptualization and formulation, the process of articulation, self of monitoring and repair, automaticity, fluency and managing talk. The first, conceptualization process comprises topics, discourse types, and communicative purposes, while in formulation process covers the ways or strategies to use vocabulary, syntax and discourse level. The second, articulation process covers the process of the speaker produce the speech or the language in speech organ. The third, self-monitoring process includes the controlling all the previous steps. The forth, automaticity process refers to prior knowledge, habit, and memorizing of the sentences at the previous stages. The fifth, fluency process refers to the flow of the speech, pauses, speed of talking. The sixth, managing talk process refers to the process of controlling and managing the all the components of speaking during speaking process, such as turn taking, fluency, accuracy, and body language.

Brown and Yule (1983) cited in Richards (2008) stated that speaking has interactional function and transactional function. Interactional refers to the interpersonal which has the aim to maintain a social relationship between communicant and communicator such as gossiping and chatting. Transactional has the aim to get something done or to exchange the information. For example, when you want to buy meatball, you have to speak to the seller. Moreover, the framework of speaking function can be divided into three parts namely talk as interaction, talk as transaction and talk as performance. Luoma (2004) stated that speaking is the competence of human. Competence is the acquisition of knowledge skills and abilities in appropriate work setting (academic or non-academic setting). Some scholars define competence as the combination knowledge, skills and behavior to enhance the performance. According to Oxford Advance Dictionary, competence is (of person) having an ability, power, authority, skill, knowledge, etc, (to do what is needed). In short, speaking competence is delivering ideas of the students to the others to improve their speaking skill. Related to this issue, speaking has become a need for the students to be enhanced and evaluated based on the evaluation system which has been used by the teacher.

\section{Indicators of Speaking Competence}

Brown (2007: 141-142) explained the indicators of speaking competence if the student is able to:

1) Imitate a word or phrase or possibly a sentence (imitative).

2) Produce short stretches of oral language design to demonstrate competence in a narrow band of grammatical, phrasal, lexical, or phonological relationship. Such as prosodic elements-intonation, stress, rhythm, juncture, intensive ability (intensive).

3) Respond a very short conversation, standard greetings and small talk, simple requests and comments, and the like (responsive).

4) Take the two forms of either transactional 
language which has the purpose of exchanging The Trainer explains to the students what should be specific information, or interpersonal exchanges which have the purpose of maintaining social relationships (interactive).

5) Maintain social relationships with the transmission of facts and information (interpersonal).

6) Develop (monolog) oral production including speeches, oral presentations, and story-telling, during which the opportunity for an oral interaction from a listener is either highly limited or ruled out together (extensive).

\section{Nature of Speech Training}

Murcia (2001) pointed out that speech is one of the speaking activities which lead the speaker to inform the listeners about something.Martin and Miller (2003) pointed out that speech refers to the speaking activities which use the good expression, clear voice, and appropriate intonation to support the meaning. O'Hair, D., Rubenstain, H., and Stewart, R. (2010) stated thatSpeech is one of the speaking skills which used to deliver information either in a formal situation or informal situation. Speech is very useful for the students because speech can cultivate the students' competence in speaking. If the students have problems with the speaking skill and anxiety, the students can be trained by the teacher. Training is one of the activities which aimed to enhance the ability of someone to do something (Varderber, sellnow, and Varderber, 2012).

In short, speech training is a public speaking training which aimed to improve the students' speaking skill and minimize students' speaking anxiety in delivering a speech. Skill training is accordance with the weaknesses or problems which happen to the students related to the anxiety in public speaking. The problems can be a lack of knowledge, culture difference, negative mindset and etc, so the students are anxious in doing a speech in front of many people. By joining this training, the students are expected to cope with those problems. Public speaking skills include associated with the processes of goal analysis, audience and situation analysis, organization, delivery and self-evaluation (Varderber, Sellnow, and Varderber, 2012). The procedures of Speech Training are explained below: prepared in doing a speech. It involves writing a speech which includes speech framework (introduction, content, and conclusion).

Step 2 : $\quad$ Actualization of Presentation

The Trainer explains to the students how to open the speech, deliver the content and close the speech. Besides, the trainer also explains techniques in doing a speech, such as a memorizing, impromptu, reading text and extemporaneous technique.

Step 3 : Maximizing of Body Language and voice

The trainer elaborates to the students how to optimize body language, eye contact, clothes, intonation, stressing and facial expression

\section{Step $4 \quad$ : $\quad$ Using Visual Aids}

The trainer explains to the students how to use media or aids which support students' speech, such as power point, prezi, and other appropriate media. It also includes the use of color, font size, and background in slides presentation.

(Adapted from Wayne Burgraff , 2015 and Varderber, Sellnow, and Varderber, 2012).

\section{Speech Training with Systematic Desensitization Technique}

Systematic Desensitization was developed by Joseph Wolfe and was designed for clients with phobias and speaking anxiety is one of the phobias. Systematic Desensitization is one of the methods which can be used to reduce speaking anxiety by using several steps in relaxation. This treatment follows a process of "counter conditioning" meaning the association between the stimulus and the anxiety is weakened through the use of relaxation techniques, anxiety hierarchies and desensitization (Weiten, 2007). The simple procedures of Systematic Desensitization are (1) individuals first learn procedures for relaxation, (2) learn how to apply these to each of the anxietyproducing events that they visualize, (3) They learn to remain relaxed when they encounter these anxietyproducing situations in real life (Varderber, Sellnow, and Varderber, 2012). However, Greg (2011) divided systematic desensitization into four steps as follows.

Step 1 : Preparation

\footnotetext{
Step 1: Build a hierarchy of the anxiety-arousing stimuli including the degree of fear experienced. The students list all anxiety arousing stimuli.

Step 2: Train the students in muscle relaxation or music instrument Relaxation technique taught to the students.

Step 3: The students work with hierarchy by using relaxation technique. The students talk about anxiety and practices the relaxation technique

Step 4: Students confront the real fear.

The students are asked to practice their speech in in front of friends
} 
Advantages and Disadvantages of Systematic below: Desensitization Technique can be seen in the table

Table. 1 Advantage and Disadvantage of Systematic Desensitization

\begin{tabular}{|l|l}
\hline \multicolumn{1}{|c|}{ Advantage } & \multicolumn{1}{|c}{ Disadvantage } \\
\hline $\begin{array}{l}\text { Generally, see fewer (but not zero rates) of } \\
\text { negative behaviors }\end{array}$ & $\begin{array}{l}\text { Exposure protocol can take a lengthy } \\
\text { period of time to complete. }\end{array}$ \\
\hline
\end{tabular}

Based on the explanation above Systematic Desensitization, the researcher want to intermingle speech training and Systematic Desensitization to minimize the students' speaking anxiety.

According to Varderber,Sellnow, and Varderber (2012:25-27), the procedures of speech training with Systematic Desensitization Technique can be seen below:

The first meeting : The trainer explains to the students about Desensitization technique.

Step 1 : The students identify the anxiety causes from the greatest to the least.

Step 2 : The students are trained in muscle relaxation or musical relaxation

Step 3 : The students are faced with such real situation, such as the students speak louder about what they want outside the classroom in several minutes or researching the topic of speech in the library.

\section{The second meeting : : Preparation}

The Trainer explains to the students what should be prepared in doing a speech. It involves writing a speech which includes a speech framework (introduction, content, and conclusion).

The third meeting: Actualization

of

Presentation

The Trainer explains to the students how to open the speech, deliver the content and close the speech.

The fourth meeting : The trainer also explains techniques in doing a speech, such as memorizing, impromptu, reading a text and extemporaneous technique.

The fifth meeting

Maximizing of

Body Language and voice

The trainer elaborates to the students how to optimize body language, eye contact, clothes, intonation, stressing and facial expression

The sixth Meeting : Using Visual Aids The trainer explains to the students how to use media or aids which support students' speech, such as power point, prezi, and other appropriate media. It also includes the use of color, font size, and background in slides presentation

\section{METHOD}

The research was conducted in the English Department of one of private universities in Kendari, Southeast Sulawesi. The research consisted of sixteen meetings which started in the beginning of March until June 2016. This study used an experimental research. The population of the study was all students in the fourth semester. The sample of this study only one class which consisted of 25 students. The instruments of this study were speech test, observation and note taking. The data were analyzed quantitatively and qualitatively. The first, the quantitative data were analyzed by using SPSS 22 . The qualitative data were analyzed by using coding.

\section{FINDINGS AND DISCUSSION}

\section{FINDINGS}

Prestest and Posttest of Students' Speech

Table 1 Pretest of students' speech

\begin{tabular}{|c|c|c|c|c|}
\hline Class limit & Class Boundaries & Frequency & & \\
\hline $58-61$ & $57.5-61.5$ & 1 & Mean & 67.36 \\
\hline $62-65$ & $61.5-65.5$ & 7 & Mode & 66.5 \\
\hline $66-69$ & $65.5-69.5$ & 11 & Median & 66.7 \\
\hline $70-73$ & $69.5-73.5$ & 3 & SD & 4.61 \\
\hline $74-77$ & $73.5-77.5$ & 1 & & \\
\hline $78-81$ & $77.5-81.5$ & 2 & & \\
\hline Total & & 25 & & \\
\hline
\end{tabular}

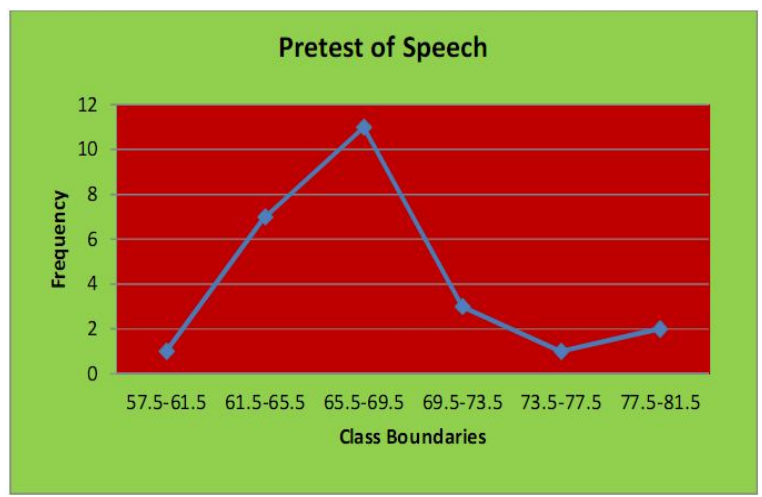

Figure 1 Pretest of Speech

Based on the calculation result, the table or figure above, it shows that the highest score is 78 and the lowest is 58. The interval is 3 and the number of class is 6 . Furthermore, it is found that the mean is 67.36 , the mode is 66.5 , the median is 66.7 and the standard deviation is 4.61 .

Table 2 Posttest of students' speech

\begin{tabular}{|c|c|c|c|c|}
\hline Class limit & Class Boundaries & Frequency & & \\
\hline $67-70$ & $66.5-70.5$ & 4 & Mean & 79.080 \\
\hline $71-74$ & $70.5-74.5$ & 2 & Mode & 80.57 \\
\hline $75-78$ & $74.5-78.5$ & 1 & Median & 80.5 \\
\hline $79-82$ & $78.5-82.5$ & 10 & SD & 5.892 \\
\hline $83-86$ & $82.5-86.5$ & 6 & & \\
\hline $87-90$ & $86.5-90.5$ & 2 & & \\
\hline Total & & 25 & & \\
\hline
\end{tabular}




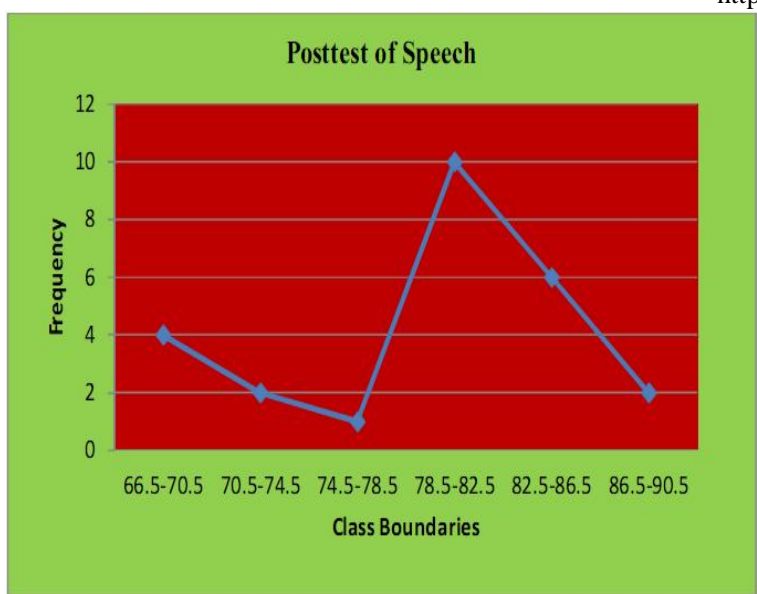

Figure2 posttest of Speech

Based on the calculation result, it shows that the highest score is 88 and the lowest is 67 . The interval is 3 and the number of class is 6 . Furthermore, it is found that the mean is 79.080 , the mode is 80.57 , the median is 80.5 and the standard deviation is 5.892 .

\section{Summary of Findings}

Based on table 1 and 2 , it can be concluded that students' speech score got improvement from pretest to posttest because the mean score of the students in pretest was 67.36, while the mean score of the students' speech for posttest was 79.080. It indicated that there was significant improvement of the students' speaking competence.

\section{DISCUSSION}

Students have joined Speech Training with Systhematic Desensitization Technique (STSDT). The students got improvement in terms of speaking competence from pretest to posttest. STSDT is very useful for the students because the students got many inputs such as how to open, deliver and close the speech. Besides, the students learned about speaking elements, such as fluency and accuracy. According to Weiten (2007), Systematic Desensitization is useful for analyzing the students' problems either anxiety or speaking problems from the highest priority until the least one.

After knowing the students' problems, the lecturer or trainer can solve the problems by giving relaxation movements and speech training to improve the students speaking competence. Varderber,Sellnow, and Varderber (2012) also said that Speech training could improve the students' ability in giving a speech because in speech training, the students are trained to be better speaker. Furthermore, the students could improve their speaking competence because the students actively participated in giving a speech, asking a question, answering question, discussing and practicing their speech. Besides, the students had high motivation to join the training because the training made them happy and enjoyable. As (Ur) stated that the characteristics of speaking successfully are talking a lot, high motivation, high participation.

Based on the implementation of Speech Training with Systematic Desensitization Technique, the students got improvement in terms of speaking competence. However, the students had problems in terms of grammar, pronunciation, repetition, body language, mother tongue, eye contact, intonation, diction and topic of the speech. Ur (2012) stated that the students problems in speaking are nothing to say, inhibitation, fluency, accuracy, and low participation. For three classes, most of the students got those problems before treatment and after treatment. However, the mistakes were fewer after the students got treatment or speech training with three different techniques for three classes.

\section{CONCLUSION AND SUGGESTION}

In conclusion, the students got improvement in terms of speaking competence after joining Speech Training with Systhematic Desensitization Technique (STSDT). It was proved by the calculation result of the mean score of the students' speech for pretest and posttest. Besides, the students were enthusiastic in joining the training. Next, further researcher could conduct the same research but in different scope and design.

\section{REFERENCES}

[1]. Brown, H. D. 2007. Principles of Language learning and Teaching $5^{\text {th }}$ Edition. New York: Pearson Education, Inc.

[2]. Burns, A. and Goh, C. 2012. Teaching Speaking. New York: Cambridge University press

[3]. Cameron, L. 2001. Teachinglanguage to young learners. Cambridge: Cambridge University Press.

[4]. German, K. et al. 2004. Principles of public speaking (15th ed.). Boston: Pearson.

[5]. Harmer, J. 2007.The Practice of English Language Teaching (Longman Handbooks for Language Teacher).New York: Longman Inc.

[6]. Jhonson, D.W., Jhonson, R.T. \& Smith, K. 2006.Active Learning: Cooperative in the College Classroom $3^{\text {rd }}$ Edition. Edina MN: Interaction Book Company

[7]. Liu, M. \& Huang, W. (2011). “An exploration of foreign language anxiety and English motivation".Education Research International, 8.http://dx.doi.org/10.1155/2011/493167/.

[8]. Louma, S. 2004.Assessing Speaking. Cambridge: Cambridge University Press.

[9]. Lyons, J. 2001. Semantics. Cambridge: Cambridge University Press.

[10]. Martin, D. and Miller. C. 2003. Speech and Language Difficulties in the Classroom $2^{\text {nd }}$ Edition.London: David Fulton Publishers.

[11]. Nation, I. S. P. \& Newton, J. 2009. Teaching ESL/EFL Listening and Speaking. New York: Routledege, Taylor and Francis.

[12]. O'Hair, D., Rubenstain, H., Stewart, R. 2010. A Pocket Guide to Public $3^{\text {rd }}$ Edition. Boston: Bedford/St. Martin's.

[13]. Olivares-Cuhat, G. (2010). "Relative importance of learning variables on L2 performance".Linguistik online, 43(3):99116.

[14]. Osborn, M. \& Osborn, S. (2014). Public speaking: finding your voice 10th ed. Boston: Houghton Mifflin. 
[15]. Richards, J. C. (2008). Teaching listening and speaking: from theory and practice. Cambridge: Cambridge University Press.

[16]. Schmitz, A. 2012.Public Speaking: Practice and Ethics. a Creative Commons by-nc-sa 3.0

[17]. Thornbury, S. 2005. How to Teach Speaking. New York: Pearson Education Ltd, Longman.
[18]. Ur, P. 2012. A Course in language teaching practice and theory $2^{\text {nd }}$ Edition. United Kingdom. Cambridge University Press.

[19]. Varderber, R. F., Sellnow, D. D., and Varderber, K. S. (2012).The challenge of effective speaking $15^{\text {th }}$ edition. USA: Wadsworth Cengage Learning. 